\title{
Influence of Selected School Factors on Pupils' Progression in Public Primary Schools in Trans - Nzoia West Sub - County, Kenya
}

Wasilwa Evans Wekesa ${ }^{1 *}$, Prof Kanjogu, John Kiumi ${ }^{2}$, Dr. Thuku Stephen Ndichu ${ }^{3}$

${ }^{1}$ Secondary School Teacher, Department of Curriculum and Education Management, Laikipia University Kenya

${ }^{2,3}$ Lecturer, Department of Curriculum and Education Management, Laikipia University, Kenya

DOI: 10.36348/JAEP.2019.v03i09.002

| Received: 12.09.2019 | Accepted: 19.09.2019 | Published: 29.09 .2019

*Corresponding author: Wasilwa Evans Wekesa

\section{Abstract}

The study sought to investigate the extent to which selected, school based factors contributed to pupils' low progression in primary schools in Trans-Nzoia West Sub-County. The study adopted ex-post facto research design. The target population was 1815 teachers drawn from 91 public primary schools. Data was collected from a sample of 313 teachers through self-administered questionnaires. Proportionate, stratified and simple random sampling techniques were used to select the subjects. The teachers' questionnaires were piloted in 5 schools in Bungoma North Sub- County and their reliabilities established after testing using the internal consistency method and Cronbach Alpha coefficient of 0.92 was realised. Data was analysed using both descriptive and inferential statistics with the aid of the Statistical Package for Social Sciences (SPSS) version 21. Data was described and summarised using frequencies and percentages while hypotheses were tested at the .05 level of significance and using simple regression analysis. The results revealed that school factors influence progression of pupils in the public primary school. The results of the study may inform the Ministry of Education, Boards of Management, parents and teachers in Trans-Nzoia West Sub-County and the country at large on factors to be addressed to enhance pupils` progression in public primary schools in the sub-county.

Keywords: School based, progression, influence.

Copyright @ 2019: This is an open-access article distributed under the terms of the Creative Commons Attribution license which permits unrestricted use, distribution, and reproduction in any medium for non-commercial use (NonCommercial, or CC-BY-NC) provided the original author and sources are credited.

\section{INTRODUCTION}

Education is considered as a basic human right, an end in itself and an intrinsic element of the social development process. Provision of education opportunities to all has been a key objective of the government of Kenya. The guiding principle has been that every Kenyan has a right, regardless of the socioeconomic status, to primary education (Republic of Kenya [1]. The Basic Education Act 2013 underlines the right of every child to access free and compulsory education [2]. Key among the goals of education in Kenya is that it should prepare and equip the youth with desirable knowledge, skills and positive attitudes to enable them to play an effective role in society, and so enjoy a meaningful and satisfying life.

According to Johnson [3], education enhances work productivity in the formal and informal sector, a factor that increases one's employment opportunities and consequently one's social mobility. This iw why the demand for education has always been rising and in line with this, the government continues to spend heavily on educational programs. The introduction of
Free Primary Education (FPE) in 2003 in Kenya is a manifestation of the importance attached to it. This policy has an international backing and credibility as this is part of the Sustainable Development Goals (SDGs) and other internationally agreed protocols [4]. Because of public financing of FPE in Kenya, demand for primary education has risen. In an effort to meet the rising demand for education, the Kenya government allocates a higher proportion of the budget on education than other sectors of the economy to have all school going age children in school in order to realise access to education.

In the US, there are two categories of influence affecting progression rates in education, push and pull factors. Push effects are factors located within the school that negatively impact on the students and are connected to the environment which make students to reject the ideas of schooling. Such factors include failing in exams and suspension for poor performance. Some schools have policies whereby students who fail or miss a number of lessons and exams, could not be allowed to continue. External factors, on the other hand, are the pull factors. These may include family issues 
like taking care of family members, teenage pregnancy among the youth and the negative influence of peer group on fellow pupils in schools. These factors interfere with students' progression and success in education [5].

Studies in Brazil by Gomes and Hanushan [6], have found that low progression still exists in Brazil but most predominant in rural areas. This has been attributed to the existence of income generating opportunities where the pupils engage in to earn income. Poverty interferes with pupils' progression as they stay more outside school to fend for money instead of learning. In Niger in 2006 and Burkina Faso in 2003, more than one-quarter of 14-year-old children who started school completed the primary cycle of education [7]. This, partially explained by the high opportunity cost of the over age students and increasing societal demands such as marriage, fending for the rest of the family and taking care of the elderly in the community undermines progression of pupils in schools.

Progression of pupils in public primary schools in Kenya faces class repetition as a very serious challenge. Repetition is a process where pupils learn in one class for more than one year. Repetition is one of the factors that cause dropouts and subsequently undermine pupil's progression. Pupils repeat classes for two or more years either forcefully by the school administration or by parents are convinced that the idea is good for their pupils. This demotivate pupils, as they grow older than the grade age and dropout before graduating primary level [2]. Repetition is a contentious issue as it greatly undermines pupils' progression rates from one class to the next, which in turn curtail the country's objective to realise free and compulsory primary education to all school going age children.

According to UNESCO [8], 14.4 million pupils repeated primary grades in Sub-Saharan Africa in 2012, representing more than one third of the global total. Some countries promote a system of "Social Promotion" which allows pupils to be promoted to the next grades irrespective of their performance, while other countries have instituted more or less strict policies of education, conditioning promotion to higher grades on ability and educational achievements. For example, countries like Netherlands, Austria, Portugal, and Belgium, pupils repeat a year or more by the end of compulsory schooling while countries like Norway, Sweden, Japan and Great Britain have no grade repetition. From the research findings by UNESCO there is need for a better remedy to be found through further research to fill the existing gap of grade repetition in order to enhance progression.

The Basic Education Act 2013, CAP 35 (2) states that 'No pupil admitted in a school, subject to sub-section (3) shall be held back in any class or expelled from school [1]. A majority of schools usually contravenes this. There remains room to find out why the the government policy has not been implemented to the later. Children with greater opportunities to earn income are likely to be taken out of school and be involved in work if parents need additional income [6]. A report by Ministry of Education in 2007 indicates that $58 \%$ of the Kenyan population is living below the poverty line. This leads to inability of the poor to meet education costs for their children. Consequently, why should the issue of poverty remain a barrier to the education progression of pupils who end up withdrawing from school to engage in domestic work in order to support their families meet basic needs and yet the government has introduced free and compulsory basic education?

In Kenya, the progression of pupils in public primary schools has continued to face the impact of persistent dropout [8]. Dropout is the premature withdrawal of pupils from school before they sit for Kenya Certificate of Primary Education (KCPE). All school going age children should be in school with a view to making the nation literate. Kenya has also subscribed to SDGs in order to enhance achievement of the country's Vision 2030 growth agenda. The inception of FPE in 2003 in Kenya increased pupil enrolment and consequently pressure on the physical facilities in schools [9]. This resulted in overcrowding in existing classrooms and by implication, lack of enough teaching personnel to match the increasing pupil population. The eminent impact was that the quality and hence desired standards in education was compromised since teachers were unable to handle the increased number of pupils effectively.

Overcrowded classrooms and teacher shortage greatly influenced pupils' progression rates because some pupils withdrew from school, a factor that affected negatively on attainment of free and compulsory primary education in the country [2]. The pressure under which pupils in primary schools' work is a lot. They are taught in congested classrooms and have short holidays. These burdens have reduced children's playtime and affected their motivation for learning. The consequences are that their performance deteriorates and in the end, dropout of school, influencing progression of pupils in schools [10]. There is urgent need for more research to be done in order to improve on the existing situation.

Nationally, the vast majority $(90 \%)$ of the school-aged children in Kenya are attending school. However, progression through the primary cycle is slow. On average, among children aged 6-13 years, the grade gap- that is the difference between the expected grade for their age and the grade in which the child is enrolled is 2 years. For example, the average 13-year old attends standard 6 rather than standard 8 . Most of the out of schoolchildren were found in arid counties such as Baringo, West Pokot and Urban Districts with 
large slums populations such as Nairobi North [11]. This is an indicator of poor progression because pupils leave school before completing primary level.

UNESCO, in a study in 2005 in nine sampled districts, which include: Embu, Gucha, Kisumu, Kajiado, Nairobi, Mwingi, Kwale and Taita Taveta, established that, while enrolment rose from 74,410 in 2002 to 92,9742003 in the 162 sampled schools, the number dropped to 88,356 in 2004 , indicating a 5 percent drop. A number of factors explain this situation: unfriendly learning environment, child labour and poverty. Over age in some pupils, has been cited as an indicator causing declining progression in primary schools. Only a quarter of the pupils are actually in a grade that is suitable for their age, while 44 percent are over-age for their grade by two or more years. Repetition was noted as a common feature in most schools, indication that the education system undermines progression of pupils. In the sample, 7.7 percent of the enrolled pupils repeated their classes. The proportion of the repeaters is high and this contravenes the official ministry of education policy that outlaws repetition [4]. From these findings there is need to find a lasting solution to improve on progression.

According to Gathura [12], in Kenya, out of the 1.3 million pupils who enrolled in class one in 2005 , only 840,000 sat for the KCPE examination in 2012. This represents $33 \%$ dropout rate. This is an indicator of poor progression of pupils in middle classes. To confirm this state of low progression in primary schools, Trans-Nzoia West Sub-county, where the researcher will carry out the study, is no exception in this prevailing practice. Table 1 clearly illustrates this scenario.

Table-1: Primary School Progression per cohort joining Class One from 2006 to 2009 in Trans-Nzoia West SubCounty

\begin{tabular}{|c|c|c|c|c|c|c|c|c|}
\hline & \multirow{2}{*}{\multicolumn{2}{|c|}{$\begin{array}{l}\text { COHORT ONE } \\
\text { FROM } 2006 \text { TO } 2013\end{array}$}} & \multirow{2}{*}{\multicolumn{2}{|c|}{$\begin{array}{l}\text { COHORT TWO } \\
\text { FROM 2007 TO } 2014\end{array}$}} & \multirow{2}{*}{\multicolumn{2}{|c|}{$\begin{array}{l}\text { COHORT THREE } \\
\text { FROM } 2008 \text { TO } 2015\end{array}$}} & \multirow{2}{*}{\multicolumn{2}{|c|}{$\begin{array}{l}\text { COHORT FOUR } \\
\text { FROM 2009 TO } 2016\end{array}$}} \\
\hline & & & & & & & & \\
\hline CLASS & $\begin{array}{l}\text { Enrolment } \\
\text { per class }\end{array}$ & $\begin{array}{l}\% \text { of the } \\
\text { cohort per } \\
\text { class }\end{array}$ & $\begin{array}{l}\text { Enrolment per } \\
\text { class }\end{array}$ & $\begin{array}{l}\% \text { of the } \\
\text { cohort } \\
\text { per class }\end{array}$ & $\begin{array}{l}\text { Enrolment } \\
\text { per class }\end{array}$ & $\begin{array}{l}\% \text { of the } \\
\text { cohort per } \\
\text { class }\end{array}$ & $\begin{array}{l}\text { Enrolment per } \\
\text { class }\end{array}$ & $\begin{array}{l}\% \text { of the } \\
\text { cohort per } \\
\text { class }\end{array}$ \\
\hline ONE & 9972 & 100.0 & 10185 & 100.0 & 10537 & 100.0 & 12572 & 100.0 \\
\hline TWO & 9410 & 94.4 & 9854 & 96.8 & 9700 & 92.1 & 12110 & 96.3 \\
\hline THREE & 9326 & 93.5 & 9695 & 95.2 & 9660 & 91.7 & 11787 & 93.8 \\
\hline FOUR & 9011 & 90.4 & 9457 & 92.9 & 9780 & 92.8 & 11582 & 92.1 \\
\hline FIVE & 8654 & 86.8 & 9270 & 91.0 & 9608 & 91.2 & 11525 & 91.7 \\
\hline SIX & 8704 & 87.3 & 9093 & 89.3 & 9416 & 89.4 & 10973 & 87.3 \\
\hline SEVEN & 9120 & 91.5 & 9748 & 95.7 & 9890 & 93.9 & 11237 & 89.4 \\
\hline EIGHT & 4722 & 47.4 & 6125 & 60.1 & 6000 & 56.9 & 7325 & 58.3 \\
\hline
\end{tabular}

Source: Trans-Nzoia West Sub-County Education Office Enrolment Data (2006-2016)

Table 1 shows that there was a decline in progression from one class to the next in all the four cohorts except for the progression from class six to seven where enrolment went up in all the four cohorts. This could be attributed to the forced repetition of pupils in class seven to enhance the mean score at class eight. This scenario suggested that there could be more underlying factors contributing to these trends in enrolment in primary schools in the Sub-County. These factors may include school-based factors such as: school academic policies, level of financial demands on parents, nature of school rules and quality of infrastructure. The extent to which these hypothesised factors influence progression is not yet known.

The main purpose of introducing the FPE policy was to ensure that all pupils complete primary school smoothly as per the 2013 basic education act of accessing free and compulsory basic education and attainment of vision 2030 growth agenda [13]. Failure to complete basic education cycle limits future opportunities for pupils and is a drain on the exchequer. Low progression rates are a danger especially to the girl child who will grow old and tired of school and therefore become susceptible to falling pregnant and getting married. The older the child is, the greater the chances of failing to complete basic education as expected [1]. The study therefore, is to investigate the influence of school-based factors on pupils' progression in public primary schools in Trans-Nzoia West SubCounty, Kenya.

\section{METHODOLOGY}

The study adopted the ex-post facto research design. The study was conducted in Trans-Nzoia West Sub-County: one of the three sub counties in TransNzoia County. The target population of the study was all the 1815 teachers, who according to the 2015 records in the District Education Office constitute the total teaching force in the 91 public primary schools in the study area. The head teachers and teachers were the respondents because they were the best placed to give information on pupils' progression in primary schools since they interacted closely with the learners and maintained their records of enrolment and progression. To sample the subjects, the researcher used Krejcie and Morgan [14], table for determining sample size (n) in a given population $(\mathrm{N})$. Stratified sampling technique was used to sample the teachers and head teachers of three divisions. The study employed simple random sampling 
technique to select the subjects. The study used the teacher's questionnaire and head teacher's data collection form to collect data. The data collection tools were piloted for reliability using samples from five schools drawn from neighboring Bungoma North SubCounty, which did not take part in the actual study. The reliability of the questionnaire was established using the internal consistency technique of the Cronbach Alpha Coefficient. After the data collection, a codebook was prepared and used to code it. The coded data was then keyed into computer and analysed with the aid of the SPSS. Qualitative data generated by the open-ended items in the teachers' questionnaire were organised in themes pertinent to the objective of the study and described and summarised using frequencies and percentages.

\section{RESULTS AND DATA ANALYSIS Influence of School Factors on Pupils' Progression}

The influence of school factors on pupils' progress was examined as the objective of the study. Data on school factors was gathered using 10 closed ended items in the teachers' questionnaire. The teachers were asked to indicate the extend they agree with the items on school factors. Their responses were assigned scores, averaged and transformed into school factors index shown in Table 2.

Table-2: School Factors Index

\begin{tabular}{|l|l|l|l|}
\hline Item & N & Mean & SD \\
\hline Pupils have to pass terminal tests to be promoted to next class & 218 & 3.34 & 1.25 \\
\hline The pupils find the school rules unbearable & 218 & 3.06 & 1.26 \\
\hline The school generally performs poorly in KCPE & 216 & 2.97 & 1.17 \\
\hline The quality of teaching in my school is poor & 216 & 3.20 & 1.23 \\
\hline Adolescent girls are not provided with sanitary towels in the school & 210 & 2.60 & 1.25 \\
\hline Guidance and counseling services provided by the teachers is ineffective & 216 & 2.87 & 1.34 \\
\hline Pupils are forced to repeat classes when they perform poorly & 216 & 3.04 & 1.42 \\
\hline Pupils are easily influenced negatively by their peers & 212 & 3.82 & 1.09 \\
\hline My school do not have adequate number of teachers & 214 & 3.35 & 1.27 \\
\hline Pupils are not given opportunities to participate in co-curricular activities & 214 & 3.29 & 1.17 \\
\hline School Based Factors Index & $\mathbf{2 1 8}$ & $\mathbf{3 . 1 1}$ & $\mathbf{0 . 7 0}$ \\
\hline
\end{tabular}

The results in Table 2 show that the means of the items on school factors were relatively low as they ranged from $2.60(\mathrm{SD}=1.25)$ to $3.82(\mathrm{SD}=1.09)$. Items such as adolescent girls are not provided with sanitary towels in the school $(\mathrm{M}=2.609, \mathrm{SD}=1.25)$ and Guidance and counseling services provided by the teachers is ineffective $(\mathrm{M}=2.87, \mathrm{SD}=1.34)$ had low means. It means that a high percent of the respondents agreed with them and a reasonable percent did not. These findings imply that there are inadequacies in the provision of sanitary towels and guidance and counseling services. However, the mean $(\mathrm{M}=3.82$, SD $=1.09$ ) of "Pupils are easily influenced negatively by their peers" was high. This implies that their peers do not easily influence pupils negatively. The school factors index $(\mathrm{M}=3.11, \mathrm{SD}=0.70)$ was moderately high given that it was measured on a 5 point scale. The results also show that the standard deviations of the items were high. This means that there were wide variations in the teachers' responses to the items.
The results in Table 2 indicated that school factors significantly influence progression of pupils in public primary schools. The results concur that failing in examinations and suspension from schools for poor performance negatively influenced progression of pupils. The results in Table 2 contradict those of UNESCO [8] which established that countries, which promote social promotion, allowed pupils to be promoted to the next class irrespective of their performance. This study noted that pupils who fail in terminal exams are forced to repeat classes. Maula [15] contradicts the findings that examinations are used positively to place pupils in various levels and courses. Admassu [2] agree with this study by asserting that pupils exposed to less play time lack extrinsic motivation, which influences progression. Oduor [16] also noted that poor sanitation facilities to a small degree caused drop out as observed by this study. Head teachers' suggestions on ways of addressing school factors that influence pupils' progression are shown in Table 3. 
Wasilwa Evans Wekesa et al; J Adv Educ Philos, Sep 2019; 3(9): 309-315

Table-3: Head Teachers Suggestions on Ways of Addressing School Factors that Influence Pupils Progression $(\mathrm{n}=$ 52)

\begin{tabular}{|l|l|l|}
\hline Suggestion & Frequency & Percentage \\
\hline Introduce feeding program & 4 & 7.7 \\
\hline $\begin{array}{l}\text { Create a conducive environment in school (good social relationships, } \\
\text { clean classrooms) }\end{array}$ & 31 & 59.6 \\
\hline Maintain discipline in schools & 12 & 23.1 \\
\hline Provide pupils with basic needs (water, sanitary) facilities & 5 & 9.6 \\
\hline Promotion to next class be automatic & 3 & 5.8 \\
\hline Involve learners in formulation of school rules & 4 & 7.7 \\
\hline Provide pupils with guidance and counseling services & 17 & 32.7 \\
\hline Improve on the physical facilities & 16 & 30.8 \\
\hline Provide learning materials & 13 & 25.0 \\
\hline Teachers be encourage to have positive attitudes towards learners & 5 & 9.6 \\
\hline Employ enough teachers & 3 & 5.8 \\
\hline Enhance pupils academic performance & 14 & 26.9 \\
\hline Motivate learners & 6 & 11.5 \\
\hline Introduce other methods of assessment besides examinations & 12 & 23.1 \\
\hline Re-admit pupils who have dropped-out (due to pregnancy, truancy) & 3 & 5.8 \\
\hline Teachers be more supportive to pupils, especially those in lower classes & 13 & 25.0 \\
\hline Reduce school levies & 5 & 9.6 \\
\hline $\begin{array}{l}\text { Strengthen programs that equip learners with life skills to reduce } \\
\text { pregnancies and drop-outs }\end{array}$ & 6 & 11.5 \\
\hline
\end{tabular}

Table 3 reveals the suggestions given by head teachers in addressing the influence school factors on pupils' progression in primary schools. The head teachers were of the view that schools should introduce feeding programs in schools $(7.7 \%)$. This would go along to improve nourishment of pupils by providing them with basic needs (9.6) and thus motivate learner in schools (11.5\%). Majority suggested that it was vital to create conducive environment in schools (59.6\%). Conducive environment would include: improved of physical facilities $(30.8 \%)$, maintain discipline in schools (23.1\%), guide and counsel pupils (32.7\%), provide learning materials $(25.0 \%)$, involve pupils in formation of school rules $(7.7 \%)$ and promotion of pupils to the next class be automatic in schools $(5.8 \%)$. Head teachers also indicated that teachers be encouraged to have positive attitudes towards learners $(9.6 \%)$, the government to employ enough teachers $(5.8 \%)$, enhance pupils academic performance (26.9\%), introduce other methods of assessment besides examination $(23.1 \%)$ and re admit pupils who have dropped out $(5.8 \%)$. They also felt that teachers should be supportive to pupils especially in lower primary classes $(9.6 \%)$, reduce school levies and strengthen programs that equip learners with life skills to reduce pregnancies and drop outs $(11.5 \%)$. Table 4 shows the teachers suggestions on ways of addressing school factors that influence pupils' progression.

Table-4: Teachers Suggestions on Ways of Addressing School Factors that Influence Pupils Progression $(\mathrm{n}=220)$

\begin{tabular}{|c|c|c|}
\hline Suggestion & Frequency & Percentage \\
\hline Improve infrastructure & 37 & 16.8 \\
\hline Provide enough learning materials & 78 & 35.5 \\
\hline Enhance the quality of teaching & 18 & 8.2 \\
\hline Employ adequate number of teachers & 31 & 14.1 \\
\hline Teachers be role models to pupils & 7 & 3.2 \\
\hline $\begin{array}{l}\text { Create a conducive learning environment in school (good } \\
\text { relationships, well maintained classes, co-curriculum activities) }\end{array}$ & 90 & 40.9 \\
\hline Discourage repetition & 61 & 27.7 \\
\hline Come up with child friendly school rules & 63 & 28.6 \\
\hline Introduce feeding programs (reduces financial burden on parents) & 13 & 5.9 \\
\hline Deal with crowding/large classes & 6 & 2.7 \\
\hline Provide sanitary facilities to girls & 15 & 6.8 \\
\hline Introduce assessment systems that do not focus on examinations & 24 & 10.9 \\
\hline Learners should not be categorised by performance & 7 & 3.2 \\
\hline $\begin{array}{l}\text { Provide guidance and counseling services to assist learners manage } \\
\text { challenges they face in school }\end{array}$ & 51 & 23.2 \\
\hline
\end{tabular}


Table 4 reveals that majority $(40.9 \%)$ of the teachers were of the view that creating conducive learning environment in school and providing enough learning materials $(35.5 \%)$ would promote progression of pupils in public primary schools. Teachers also suggested that the head teachers should make schools more child friendly (28.6\%), discourage repetition $(27.7 \%)$ and provide guiding and counseling services to assist learners manage challenges they face in schools (23.2\%).These steps would greatly promote progression in public primary schools. They were also of the views that improved infrastructure $(16.8 \%)$, enhance quality of teaching $(8.2 \%)$, employ adequate number of teachers $(14.1 \%)$, introduce assessment systems that do not focus on exams alone $(10.9 \%)$ and provide sanitary facilities to girls $(6.8 \%)$ would support progression. Teachers should introduce school feeding programs $(5.9 \%)$, learners should not be categorised by performance $(3.2 \%)$, teachers be role models $(3.2 \%)$ and deal with large classes to a minor extend would promote pupils' progression in schools.

The influence of school based factors on pupils progress was established using simple regression. School based factors index was regressed on pupils' progression as presented in Table 5.

Table-5: Results of Regressing School Factors on Pupils' Progression

\begin{tabular}{|l|l|l|l|l|l|}
\hline Model & Unstandardised Coefficients & Standardised Coefficients & t-value & p-value \\
\hline & B & Std. Error & Beta & & \\
\hline Constant & 54.191 & 4.042 & & 13.406 & .000 \\
\hline Personal factors & 6.073 & 1.266 & .311 & 4.796 & .000 \\
\hline $\mathrm{r}=.311 ., \mathrm{r}^{2}=.097, \mathrm{~F}(1,215)=22.995, \mathrm{p}=.000$ & & \\
\hline
\end{tabular}

The regression test results indicate that that there was a positive $(r=.311)$ relationship between school based factors and pupils' progression was also positive. School based factors explained $9.7 \%\left(\mathrm{r}^{2}=\right.$ .097) variation in pupils progression. The linear equation relating the two constructs was:

$$
\begin{aligned}
& \text { Pupils progression }=54.191+6.073 \text { School } \\
& \text { factors }
\end{aligned}
$$

The linear model fitted the data well as it was statistically significant, $\mathrm{F}(1,215)=22.995, \mathrm{p}=.000$. The results also indicate that the influence of school factors on pupils' progression was statistically significant, $\beta=.311, \mathrm{t}=4.696, \mathrm{p}=.000$. The results did not concur with the second null hypothesis, which stated that school factors do not significantly influence pupil's progression. Based on this observation, the hypothesis was rejected.

The results are in line with the view that conducive classroom environments are a requirement to the promotion of progression in schools because positive climates improve retention of pupils that lead to improved progression. Kutnick [17] in support of the study asserts, that conducive classroom environment influences progression of pupils.

Gachungi [18] who did a study in Nyeri Municipality contradicts the findings of this study by stating repetition increases chances of getting better grades. The study suggests promotion to the next grade be automatic. Gathura [12] agrees with Gachungi in his findings where he states half of the pupils repeat classes and eventually drop out. Kwamboka [19] further supports by asserting that class repetition denies learners their right to sitting exams at the right age.
Lack of enough sanitary facilities influences pupils' attendance of school and eventually drop out [16]. This is in harmony with the findings of this study. Sifuna [20] established that use of examinations to evaluate learner' abilities discourages low performers from attending school. This agrees with this study which found out that alternative ways of evaluation should be used in schools to make school more child friendly. O'Brien [16] in support of the study found that schools should be free of harsh rules and regulations to enhance smooth progression of pupils in public primary schools.

\section{CONCLUSION}

The study hypothesis tested whether school factors significantly influenced pupils' progression. The results of the test showed that the relationship between school factors and pupils' progression was positive.

\section{REFERENCES}

1. Cameron. L. (2005). Primary completion rates: E.P.D.C Technical Paper Wp-09-01.

2. Admassu, K. (2013, August, 2). "African Population and Health Research CenterEducational Research." The Daily Nation. Press. p.12.

3. Johnson, T. (2011). Education Essays. Retrieved from www.studymode.com

4. Orodho, J.A.., Waweru, P. N., Getange, K. N., \& Miriti, J. M. (2013). Progress towards Attainment of Education for All (EFA) among nomadic pastoralists: Do home-based factors make a difference in Kenya? Research on Humanities and Social Sciences, 3(21), pages 54-67.

5. Prevatt, F. (2006). School Dropout / Tinamy PhD. Florida State University.

6. Gomes, J., \& Hanushan, E. (1994). Causes and consequences of grade repetition: Evidence from 
Brazil. Economic Development and Cultural Change, 43, 117-148.

7. Ricardo, S. (2010). School Dropouts: Patterns, Causes, Changes and Policies. Paris: UNESCO.

8. UNESCO. (2013). Global Education Digest 2013. Montreal. UIS

9. Aker, J. C., \& Mbiti, I. M. (2010). Mobile phones and economic development in Africa. Journal of economic Perspectives, 24(3), 207-32.

10. Sifuna, D. N. (1990). Development of Education in Africa: The Kenya Experience Nairobi Society: University of Glasgow Transfer from First to Second-Level Schooling Dublin: Marino Institute of Education. United State: Economics of Education Review, 409-420

11. Uwezo. (2015). Are children learning? The state of Education in Kenya in 2015 and beyond. Nairobi: Twaweza East Africa

12. Gathura. G. (2014, January 5). "Shock of Three Million Pupils Repeating Classes Yearly." The Daily Nation Press, 12.

13. Aduda, D. (2014, January 2). (Education Editor). "Low score of worst performers raises queries on teaching." The Daily Nation Press. p.4.c

14. Krejcie, R.V., \& Morgan, D.W. (1970). Determining a sample size for research activities
Educational and Psychological Measurements. NEA Research Bulletinvo 138.

15. Maula, E. (2012). Factors influencing academic performance of pupils in public secondary schools in Teso South District. (Thesis) University of Nairobi, Kenya.

16. Oduor, A. (2014, May, 29). (Education Editor). "More boys dropping out of school." The Daily Nation, 8

17. Kutnick, P. (2000). Girls, boys and school achievement: Critical comments on who achieves in schools and under what economic and social conditions achievements take place - A Carribean Perspective. International Journal of Education Development, 20, 65-84.

18. Gachungi, J. M. (2011). "Factors Contributing to Educational Wastage in Public and Private Secondary Schools in Municipality Division, Nyeri District, Central Province. Nairobi." M, E, D Thesis, UON.

19. Kwamboka, C. (2003, July 25). "How to write and defend a proposal successfully." The Standard, 8.

20. Sifuna, D. N. (1986). The vocational curriculum in primary education in Kenya: An evaluation. Prospects, 16(1), 123-134. 